\title{
Peran Kemandirian Belajar dalam Memediasi Pengaruh Motivasi Berprestasi terhadap Prestasi Belajar Mahasiswa Selama Pembelajaran Daring
}

\author{
Nurul Matsani*1, Mohamad Arief Rafsanjani² \\ 1,2Program Studi Pendidikan Ekonomi \\ Universitas Negeri Surabaya \\ Surabaya, Indonesia
}

e-mail: nurul.17080554053@mhs.unesa.ac.id*1, mohamadrafsanjani@unesa.ac.id²

\begin{abstract}
Abstrak
Riwayat Artikel Tanggal diajukan: 20 April 2021

Tanggal diterima : 9 Mei 2021

Tanggal dipublikasikan: 25 Juni 2021

Penelitian ini bertujuan untuk menganalisis serta menguji peran kemandirian belajar dalam memediasi pengaruh motivasi berprestasi terhadap prestasi belajar mahasiswa selama pembelajaran daring. Responden penelitian ini yaitu 158 mahasiswa aktif Jurusan Pendidikan Ekonomi UNESA angkatan 2018. Teknik pengumpulan data melalui kuesioner dan dokumentasi, kemudian data dianalisis menggunakan Uji SEM (Structural Equation Modelling). Hasil dari penelitian ini diperoleh bahwa motivasi berprestasi berpengaruh secara langsung dan signifikan terhadap prestasi belajar. Motivasi berprestasi berpengaruh langsung dan signifikan terhadap kemandirian belajar. Kemandirian belajar tidak berpengaruh secara langsung dan tidak signifikan terhadap prestasi belajar, serta motivasi berprestasi berpengaruh tidak langsung terhadap prestasi belajar melalui kemandirian belajar dengan nilai total sebesar $20 \%$.
\end{abstract}

Pengutipan:

Matsani, N.,

Rafsanjani, M.,A.

(2021). Peran

Kemandirian

Belajar Dalam

Memediasi

Pengaruh

Motivasi

Berprestasi

terhadap Prestasi

Belajar

Mahasiswa

Selama

Pembelajaran

Daring. Jurnal

Pendidikan

Ekonomi

Undiksha, 13(1)

9-21

http://dx.doi.org/1

$0.23887 /$ ijpe.v13i

1.33910

Kata kunci: motivasi berprestasi; kemandirian belajar; prestasi belajar.

\begin{abstract}
This study aims to analyze and examine the role of independent learning in mediating the effect of achievement motivation on student achievement during online learning. Respondents of this study were 158 active students of the Department of Economic Education, UNESA, batch 2018. Data collection techniques were through questionnaires and documentation, then the data were analyzed using the SEM (Structural Equation Modeling) test. The results of this study indicate that achievement motivation has a direct and significant effect on learning achievement. Achievement motivation has a direct and significant effect on learning independence. Learning independence has no direct and insignificant effect on learning achievement. and achievement motivation has an indirect effect on learning achievement through independent learning with a total value of $20 \%$.
\end{abstract}

Keywords : achievement motivation; independence learning, learning achievement .

\section{PENDAHULUAN}

Revolusi industri 4.0 sangat berdampak pada perubahan pola kehidupan manusia. hal ini dibuktikan berkembang pesatnya mesin dengan industri 
sampai teknologi, informasi dan komunikasi. Pesatnya perkembangan di atas membawa pengaruh terhadap kemudahan dalam segala hal. Tidak dapat di pungkiri bahwa perkembangan teknologi ini dapat menjadi potensi kuat bidang pendidikan dalam menghadapi tantangan pendidikan abad 21 yang sangat kompleks. Menurut Husaini, (2014) berkembangnya teknologi pada dunia pendidikan dapat digunakan sebagai media pembelajaran searah maupun secara interaktif. Dari perkembangan inilah yang kemudian muncul adanya inovasi pembelajaran jarak jauh dimana pembelajaran ini tidak lagi bergantung pada interaksi secara langsung di dalam kelas.

Pembelajaran dalam jaringan (pembelajaran daring) yang termasuk dalam pembelajaran jarak jauh merupakan salah satu alternatif yang diambil seiring dengan adanya pandemi COVID-19 di Indonesia. Pengalihan pembelajaran dari tatap muka menjadi pembelajaran dalam jaringan (pembelajaran daring) ini ditetapkan melalui surat edaran Kementrian Pendidikan dan Kebudayaan (Mendikbud) Nomor 36962/MPK.A/HK/2020 dengan tujuan untuk memutus dan meminimalisir penyebaran COVID-19. Pengalihan pembelajaran ini dilakukan merata pada seluruh jenjang pendidikan baik formal maupun non formal. Dengan demikian seluruh lembaga pendidikan harus siap, sigap dan dapat beradaptasi dengan kondisi pembelajaran daring.

Perguruan tinggi sebagai lembaga pendidikan formal juga harus siap dan dapat beradaptasi pula dengan kondisi pembelajaran daring. Pembelajaran daring pada jenjang perguruan tinggi di rasa cukup efektif mengingat sebagian besar dari perguruan tinggi sudah memiliki platform Virtual Learning (V-Learning) untuk pembelajaran jarak jauh mahasiswanya. Hal ini sejalan dengan pendapat Singh, et $\mathrm{Al}$, (2005) yang membuktikan terjadinya hubungan simbiosis mutualisme antara dosen dengan mahasiswa melalui pembelajaran daring ini. Menurut Waskitoningtyas (2020) manfaat pembelajaran daring bagi mahasiswa adalah pembelajaran yang bersifat dinamis, bisa dilakukan kapan dan dimana saja, sehingga pembelajaran tidak selalu harus berada di dalam kelas. Melalui pembelajaran daring pula interaksi antar mahasiswa dapat terjalin dengan kuat. Sedangkan manfaat pembelajaran daring dari sisi dosen adalah dapat meningkatkan profesionalitas kerja melalui pengembangan metode pembelajaran serta dapat memberikan peluang bagi dosen untuk dapat melakukan evaluasi pembelajaran secara efektif dan efisien.

Dari pernyataan di atas maka pembelajaran daring dapat dinyatakan efektif untuk di implementasikan utamanya pada jenjang perguruan tinggi. Namun pendapat Pilkington (2018) menyatakan tidak semua pembelajaran konvensional dapat dialihkan ke pembelajaran daring. untuk mengetahui apakah pembelajaran daring efektif dan berhasil diterapkan diperguruan tinggi maka terdapat beberapa kriteria seperti dengan melihat keberhasilan belajar mahasiswa selama pembelajaran daring. Keberhasilan belajar dalam jenjang perguruan tinggi sendiri berupa nilai IPK (Indeks Prestasi Akademik) mahasiswa selama melakukan pendidikan di perguruan tinggi.

Keberhasilan setiap individu dalam menggapai prestasi belajar secara maksimal dalam suatu pembelajaran tentunya dipengaruhi oleh beberapa faktor-faktor. Menurut Slameto (2013) prestasi akademik dipengaruhi oleh 2 faktor pokok yakni faktor internal dari dalam setiap individu itu sendiri dan juga faktor eksternal dari luar diri setiap individu. Faktor internal mencakup segala kebutuhan belajar dari dalam diri setiap individu seperti perhatian, minat, motivasi, bakat kebiasaan belajar dll. Sedangkan faktor eksternal merupakan faktor yang mencakup keperluan belajar dari luar diri setiap individu seperti lingkungan belajar, kondisi ekonomi, kurikulum, media, teman sebaya dll.

Berdasarkan uraian tersebut banyak
faktor yang dapat mempengaruhi
pencapaian prestasi belajar mahasiswa,
namun dalam penelitian ini peneliti hanya
membatasi pada faktor yang relevansinya
sangat dekat dengan fenomena selama
pembelajaran daring. salah satu faktor yang
memiliki relevansi dengan pembelajaran
daring diantaranya adalah faktor motivasi
berprestasi dan kemandirian belajar. faktor


kemandirian belajar disini di dasarkan pada hasil penelitian yang telah dilakukan oleh Utami (2019) yang menyatakan bahwa kemandirian belajar sangat diperlukan dalam menunjang keberhasilan mahasiswa selama pelaksanaan pembelajaran di masa covid-19. Sedangkan faktor motivasi berprestasi di dasarkan pada penelitian Selvi, (2010) yang menyatakan motivasi dapat membentuk lingkungan pembelajaran daring yang kondusif sehingga hal ini akan berdampak pula pada pencapaian prestasi belajar setiap individu.

Dilihat dari hasil wawancara yang dilakukan peneliti dengan perwakilan mahasiswa dari setiap program studi diperoleh hasil bahwa selama pembelajaran daring mahasiswa cenderung kesulitan dalam memanage kemampuannya selama pembelajaran berlangsung, selain itu terbatasnya waktu dan komunikasi dalam pembelajaran menjadikan mahasiswa mengulur-ulur waktu dalam mengerjakan tugas serta masih bergantung dengan orang lain, hal ini tanpa disadari berpengaruh terhadap pencapaian prestasi belajar mahasiswa selama pembelajaran daring yang kurang maksimal. Oleh sebab itu, peneliti membatasi dalam kajian hanya memperhatikan faktor internal yaitu motivasi berprestasi dan kemandirian belajar sebagai faktor pencapaian prestasi belajar yang paling dekat relevansinya selama pembelajaran daring.

Kemandirian belajar dalam penelitian ini didasarkan pada teori kontruktivisme yang dikembangkan oleh Piaget (2002) yang menyatakan bahwa pembelajaran yang sebenarnya dilakukan dari pembentukan pengetahuan oleh si pembelajar sendiri. Didukung oleh penelitian Santrock (2004) yang menyatakan bahwa pembelajar yang memiliki motivasi berprestasi tinggi akan memanage kebutuhan belajarnya sendiri. Hal ini juga di dukung oleh penelitian Sobri \& Moerdiyanto (2014) dimana mereka menegaskan bahwasanya terdapat hubungan positif kemandirian belajar pada prestasi belajar. Hal ini mendorong adanya hubungan searah ketika kemandirian belajar naik dan meningkat satu-satuan dapat dipastikan pula prestasi belajar mengikuti naik dan meningkat
Keterlibatan peserta didik dalam belajar secara mandiri menggambarkan ciri khas dan karakteristik dari teori kontruktivisme. Dimana hal ini sejalan dengan kondisi pembelajaran saat ini dengan berbasis pembelajaran dalam jaringan. Menurut Allen, Romney, Dey, \& Romney (2015) pada dasarnya belajar mandiri merupakan salah satu sifat dari pembelajaran daring, sehingga dalam hal ini keterlibatan mahasiswa secara aktif dalam pembelajaran akan sangat menentukan keberhasilan belajarnya. Selain itu Kemandirian belajar sangat diperlukan mahasiswa dengan tujuan agar terlatih untuk menghadapi kompetensi dunia kerja di era globalisasi seperti saat ini. Sejalan dengan pendapat Balapumi, R., \& Aitken (2012); Mckendry, S., \& Boyd (2012); Ros, V., Keo, O., \& Sophal (2012) dalam penelitian terdahulu yang menyatakan bahwa pentingnya kemandirian belajar menjadikan hal tersebut ditetapkan sebagai tujuan pendidikan pada perguruan tinggi dibeberapa negara.

Selain kemandirian belajar, terdapat motivasi belajar pula yang menjadi predikator keberhasilan individu dalam mencapai prestasi belajar. Dalam penelitian ini motivasi berprestasi didasarkan pada pandangan Mc. Clelland (1961) melalui bukunya yang berjudul "The Achieving Society". Dalam bukunya Mc. Clelland (1961) menyatakan bahwa semakin besar motivasi seseorang dengan didukung oleh situasi dan kesempatan yang tersedia, maka akan semakin besar pula cadangan energi potensial yang dimiliki untuk meraih berbagai prestasi dalam hidupnya. Mc. Clelland (1961) menyatakan bahwa motivasi berprestasi mempunyai kontribusi sampai $64 \%$ terhadap prestasi belajar siswa. Sependapat dengan Marvianto, Ratnawati, \& Madani (2020) dalam studinya yang mendapati hubungan positif motivasi berprestasi mahasiswa pada prestasi belajar. Dibuktikan dengan adanya fakta bahwa mahasiswa dengan motivasi berprestasi tinggi cenderung menghasilkan nilai signifikansi yang juga mengikuti tinggi.

Dalam pembelajaran daring motivasi berprestasi mahasiswa sangat erat kaitannya dengan prestasi belajar, dengan motivasi berprestasi yang tinggi mahasiswa 
akan dapat menetapkan target dan tujuan serta akan cenderung melakukan kegiatan yang menantang dirinya untuk bersemangat dan antusias dalam pembelajaran. Sejalan dengan penelitian Jegede, Jegede, \& Ugodulunwa (1997) dengan adanya motivasi berprestasi seseorang akan lebih terdorong untuk bekeinginan sukses dalam meraih prestasi yang sama di kesempatan selanjutnya. Didukung pula oleh penelitian yang dikembangkan oleh Baars \& Wijnia (2018) yang menyatakan bahwa individu dengan motivasi pengaturan diri yang tinggi dapat membuktikan pencapaian keberhasilan belajar dengan baik, hal ini diikuti dengan adanya ketepatan dalam memanage dirinya.

Selain berpengaruh terhadap prestasi belajar, motivasi berprestasi juga memiliki hubungan positif dan signifikan terhadap kemandirian belajar. Motivasi berprestasi disini dapat mendorong kemandirian dalam belajar. Menurut Keirns (1999) salah satu faktor yang dapat mempengaruhi kemandirian belajar adalah motivasi berprestasi. Dengan motivasi berprestasi tinggi mahasiswa akan cenderung berkemauan untuk belajar secara individual tanpa bergantung dengan orang lain. Sejalan pula dengan hasil penelitian Huang (2008) yang menyatakan bahwa terdapat presentase pengaruh yang besar antara motivasi berprestasi terhadap prestasi belajar dibandingkan dengan faktor lainnya. Di dukung pula oleh Fitriani, Haryanto, \& Atmojo (2020) dalam penelitiannya yang menegaskan antara motivasi berprestasi dengan kemandirian belajar memiliki hubungan positif dan signifikan. Dengan adannya hubungan tersebut maka variabel kemandirian belajar sebagai variabel yang dipengaruhi oleh motivasi berprestasi dapat dijadikan sebagai variabel mediasi dalam penelitian ini.

Melalui pemaparan hubungan antar variabel di atas maka peneliti menetapkan kemandirian belajar sebagai variabel mediasi antara motivasi berprestasi pada prestasi belajar. Mengingat adanya pengaruh dan hubungan yang besar pula pada motivasi berprestasi terhadap kemandirian belajar. Selain itu, penetapan kemandirian belajar sebagai variabel mediasi dalam penelitian ini juga didasarkan pada kondisi pembelajaran saat ini yang mengharuskan mahasiswa belajar dirumah melalui pembelajaran daring sehingga dengan adanya kemandirian belajar sebagai variabel mediasi diharapkan dapat memberikan sumbangsih lebih pada dunia pembelajaran daring saat ini.

Berdasarkan uraian fenomena dan kajian teori di atas peneliti tertarik untuk menguji Peran Kemandirian Belajar dalam Memediasi Pengaruh Motivasi Berprestasi terhadap Prestasi Belajar Mahasiswa Jurusan Pendidikan Ekonomi Universitas Negeri Surabaya Angkatan 2018 Selama Pembelajaran Daring. Mengingat pembelajaran daring telah dilaksanakan sejak adanya pandemi COVID-19 sampai saat ini yang menjadikan kondisi tersebut sebagai kondisi khusus untuk diteliti. Harapannya dengan menambahkan kemandirian belajar sebagai variabel mediasi yang belum pernah dilakukan pada penelitian-penelitian sebelumnya, mahasiswa dapat mengidentifikasi kebutuhan belajar mereka melalui motivasi berprestasi serta meningkatkan prestasi belajar selama pembelajaran di rumah melalui optimalisasi peran kemandirian belajar. Sehingga pencapaian tujuan pembelajaran akan dapat dicapai dengan maksimal.

\section{METODE}

Penelitian ini merupakan Jenis penelitian eksplanatori dengan menggunakan pendekatan kuantitatif yang bertujuan untuk menganalisa hubunganhubungan antar satu variabel dengan variabel lainnya. Model dalam penelitian ini adalah sebagai berikut :

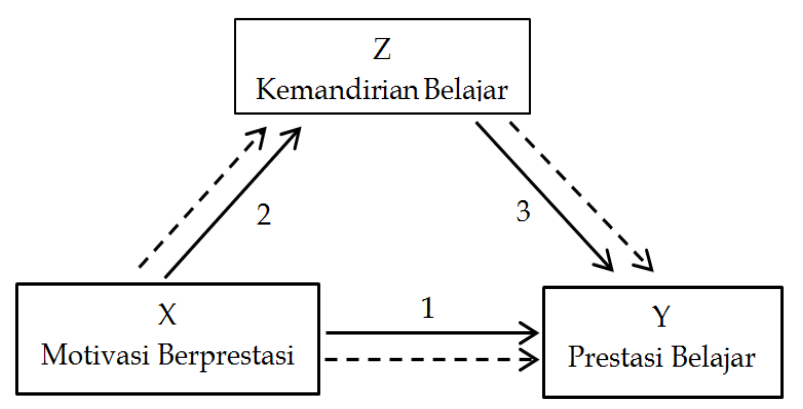

Keterangaambar 1. Model Penelitian

$\longrightarrow=$ Pengaruh secara langsung

$---\rightarrow=$ Pengaruh secara tidak langsung $\mathrm{X}=$ Variabel eksogen 
$Y=$ Variabel endogen

$Z=$ Variabel Mediasi

Populasi penelitian ini adalah mahasiswa aktif Jurusan Pendidikan Ekonomi UNESA angkatan 2018 sejumlah 251 orang yang kemudian diambil sampel sebanyak 158 orang dengan teknik pengambilan simple random sampling menggunakan rumus slovin.

Pengumpulan data dilakukan dengan menggunakan teknik kuesioner dan dokumentasi. Teknik kuesioner digunakan untuk memperoleh data dari responden terkait variabel motivasi berprestasi dan variabel kemandirian belajar. Data hasil kuesioner diukur menggunakan skala likert 4 skala. Sedangkan, teknik dokumentasi digunakan untuk memperoleh data IPK mahasiswa yang berasal dari TU Jurusan Pendidikan ekonomi.

Instrumen kuesioner motivasi berprestasi pada penelitian ini menggunakan Science Motivation Questionnaire (SMQ-II) yang diadopsi dari penelitian Glynn et al. (2009) sedangkan instrumen pada kuesioner kemandirian belajar menggunakan Self Direct Learning Readiness Scale (SDLRS) yang diadopsi dari penelitian Guglielmino et al. (1987).

Sebelum kuesioner disebarkan kepada seluruh responden, peneliti melakukan uji validitas dan reabilitas terlebih dahulu kepada 68 responden. Setelah lulus uji validitas dan reabilitas maka angket siap disebarkan keseluruh sampel.

Setelah diperoleh data maka selanjutnya dilakukan uji analisis deskriptif terlebih dahulu, kemudian data di transformasikan dari data ordinal ke data interval. Setelah data tertransformasi selanjutnya dilakukan uji Structural Equation Modelling (SEM) yang memenuhi uji validitas konvergen dan diskriminan, uji reabilitas komposit, uji asumsi goodness of fit, uji parametrik individu, uji hipotesis dan uji path analysis.

\section{HASIL DAN PEMBAHASAN \\ Hasil \\ Hasil Analisis Deskriptif \\ Dari kuesioner yang telah didistribusikan pada 158 responden dari 4}

Program Studi di Jurusan Pendidikan Ekonomi UNESA angkatan 2018 diperoleh data statistik frekuensi responden terbanyak pada penelitian ini berasal dari Program Studi S1 Pendidikan Tata Niaga dengan presentase $27,8 \%$, kemudian S1 Pendidikan Administrasi Perkantoran sebesar 27,2\%, S1 Pendidikan Ekonomi 23,5\% dan yang terkecil S1 Pendidikan Akuntansi dengan presentase $21,5 \%$.

Analisis statistik deskriptif juga dilakukan pada variabel motivasi berprestasi dan variabel kemandirian belajar. Berdasarkan perhitungan tersebut diperoleh hasil bahwa sebanyak $74,1 \%$ mahasiswa menyatakan sangat setuju memiliki motivasi berprestasi tinggi selama pembelajaran daring. Hal ini dapat dilihat dari perolehan nilai tertinggi pada variabel ini sebesar 60 dan nilai terendah sebesar 33 dengan nilai rata-rata 50,12 dan nilai median 50. Dari hasil analisis nilai tertinggi pada variabel ini adalah pada indikator motivasi instrinsik dan relevansi pribadi dengan bunyi item pernyataan "saya berpikir bahwa ilmu ekonomi yang saya pelajari akan bermanfaat bagi saya" yang memperoleh jumlah jawaban sebesar $576(91,1 \%)$.

Sedangkan, pada variabel kemandirian belajar diperoleh hasil analisis deskriptif bahwa $58,2 \%$ mahasiswa sangat setuju telah dapat belajar dengan mandiri selama pembelajaran daring. Perolehan nilai tertinggi pada variabel ini sebesar 96 dan nilai terendah sebesar 66 dengan nilai ratarata 81,87 dan nilai median 81 . Dari hasil analisis nilai tertinggi pada variabel ini adalah pada indikator berorientasi pada masa depan dengan bunyi item pernyataan "saya ingin belajar lebih giat lagi untuk dapat terus mengembangkan diri" yang memperoleh jumlah jawaban sebesar 575 (90\%).

Pada variabel prestasi belajar berupa data IPK yang telah didapat dari TU Jurusan Pendidikan Ekonomi diperoleh hasil bahwa sebanyak 131 mahasiswa sudah dapat mencapai prestasi belajar yang baik dengan predikat sangat memuaskan (cumlaude), sedangkan 27 sisanya mencapai prestasi belajar pada predikat memuaskan. Dari hasil analisis ini dapat dilihat bahwa selama pembelajaran daring mahasiswa Jurusan Pendidikan Ekonomi UNESA angkatan 2018 
tidak ada yang mendapatkan IPK pada skala $2,00-2,75$. Artinya prestasi belajar mahasiswa selama pembelajaran daring dapat dikatakan baik.

Setelah dilakukan analisis statistik deskriptif selanjutnya data ditransformasikan menggunakan aplikasi SolAnd dengan melalui metode MSI (Method of Successive Interval) dimana menurut Al-Rasyid (1994) transformasi data ini dilakukan agar data penelitian lebih akurat. Selanjutnya data yang sudah ditransformasikan menjadi data skala dilakukan pengujian SEM (Structural Equation Modelling) melalui aplikasi WarpPLS.

\section{Uji Validitas Konvergen, Divergen dan Reabilitas Komposit}

Penelitian ini telah memenuhi hasil uji SEM, mulai dari Uji Validitas Konvergen dengan faktor loading dari semua indikator > 0,40 dan dengan nilai $p$ values keseluruhan $<0,05$. Kemudian memenuhi Uji Validitas Diskriminan dengan nilai Average Variance Extract (AVE) dari variabel motivasi berprestasi sebesar 0,642 sedangkan dari variabel kemandirian belajar sebesar 0,663 dimana keduanya $>0,50$. Selanjutnya penelitian ini juga telah memenuhi uji reabilitas komposit dengan nilai cronbach alpha dari variabel motivasi berprestasi sebesar 0,860 dan dari variabel kemandirian belajar sebesar 0,940 keduanya $>0,70$. Sehingga dapat disimpulkan bahwa semua item pernyataan pada kedua variabel dinyatakan valid dan reliabel serta dapat digunakan untuk dilakukan analisis selanjutnya.

\section{Uji Hipotesis}

\section{Pengaruh Langsung}

Selanjutnya dilakukan uji hipotesis. Pada penelitian ini terdapat dua jenis pengujian yakni pengaruh secara langsung serta tidak langsung. Hasil pengujian pengaruh langsung antara variabel motivasi berprestasi $(\mathrm{X})$ terhadap prestasi belajar $(\mathrm{Y})$ melalui uji parametrik individu adalah sebagai berikut :

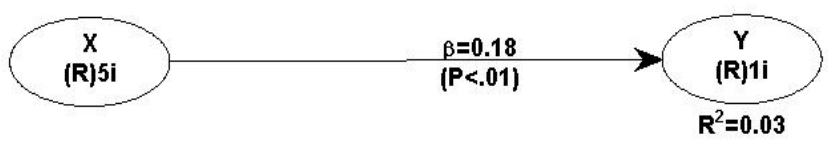

Gambar 1. Hasil Uji Hipotesis
Dari model penelitian di atas menunjukkan bahwa nilai koefisien jalur pengaruh motivasi berprestasi terhadap prestasi belajar adalah sebesar 0,181 dengan $p$ values untuk hubungan secara langsung tersebut adalah 0,01 $<0,05$ (tingkat kepercayaan 95\%). Hal ini mengindikasikan bahwa secara statistik motivasi berprestasi mahasiswa memiliki pengaruh positif dan signifikan terhadap prestasi belajar. Dengan demikian maka dapat dinyatakan Hipotesis $1(\mathrm{H} 1)$ diterima.

Untuk melihat pengaruh langsung selanjutnya antara motivasi berprestasi $(X)$ terhadap kemandirian belajar $(Z)$ dan kemandirian belajar $(Z)$ terhadap prestasi belajar ( $\mathrm{Y}$ ) yang merupakan $\mathrm{H} 2$ dan $\mathrm{H} 3$ maka dilakukan uji path analysis (analisis jalur) sebagai berikut :

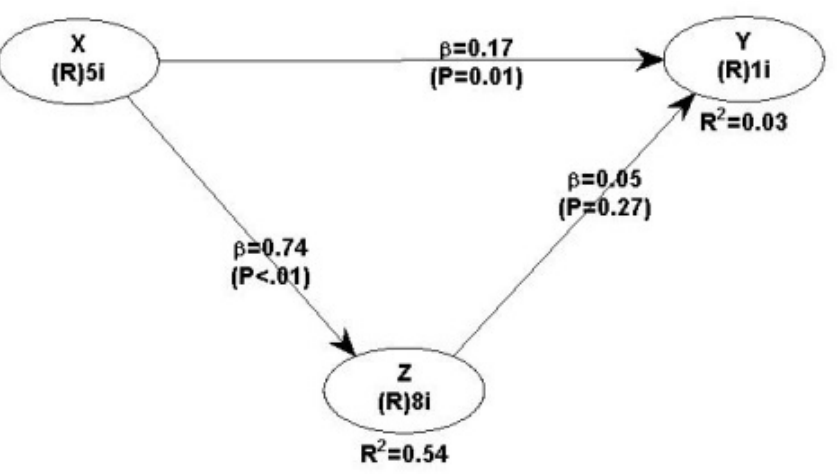

Gambar 2. Hasil Uji Hipotesis

Berdasarkan gambar 2 di atas dapat diketahui bahwa nilai standardize koefisien beta pengaruh motivasi berprestasi $(X)$ pada prestasi belajar $(\mathrm{Y})$ mengalami penurunan dari nilai pada model awal (Gambar 1). Pada model kedua koefisien jalur mengalami penurunan menjadi $0,014<0,05$ (tingkat kepercayaan 95\%). Hal tersebut menjelaskan bahwa secara statistik variabel kemandirian belajar ( $Z$ ) dapat memberikan pengaruh kontrol sehingga pengaruh motivasi berprestasi $(\mathrm{X})$

terhadap prestasi belajar (Y) dapat mengalami penurunan.

Pada gambar 2 di atas juga menunjukkan pengaruh antara variabel motivasi berprestasi $(X)$ pada kemandirian belajar (Z) memiliki nilai koefisien jalur sebesar 0,737 dengan $p$ values $0,001<$ 0.005 (tingkat kepercayaan 95\%) sehingga 
dapat disimpulkan bahwa motivasi berprestasi $(X)$ memiliki pengaruh positif dan sangat signifikan terhadap kemandirian belajar $(Z)$. Dengan demikian maka dapat dinyatakan Hipotesis $2(\mathrm{H} 2)$ diterima.

Pengaruh lain yang dapat dilihat pada gambar 2 adalah adanya pengaruh antara kemandirian belajar $(Z)$ terhadap Prestasi belajar $(Y)$ yang memiliki nilai koefisien jalur sebesar 0,047 dan $p$ values 0,274 >0,05 (tingkat kepercayaan 95\%) hal tersebut menunjukkan bahwa tidak terdapat pengaruh yang signifikan antara kemandirian belajar $(Z)$ terhadap prestasi belajar (Y). Tidak adanya pengaruh yang signifikan ini menggambarkan bahwa tidak terdapat kaitan dan hubungan antara kemandirian belajar ( $Z$ ) dengan prestasi belajar $(\mathrm{Y})$ dengan demikian maka dapat dinyatakan Hipotesis $3(\mathrm{H} 3)$ ditolak.

\begin{tabular}{cccccc}
\hline No & Variabel Penjelas & Variabel respon & Koefisien Jalur & P-values & Keterangan \\
\hline 1. & $\mathrm{X}$ & $\mathrm{Y}$ & 0,181 & 0,01 & Signifikan \\
2. & $\mathrm{X}$ & $\mathrm{Z}$ & 0,737 & $<0,001$ & Sangat Signifikan \\
3. & $\mathrm{Z}$ & $\mathrm{Y}$ & 0,047 & 0,274 & Tidak Signifikan \\
\hline
\end{tabular}

Tabel 1. Hasil Uji Hipotesis secara Langsung

Pengaruh Tidak Langsung

Tabel 2. Hasil Uji Hipotesis Pengaruh Tidak Langsung

\begin{tabular}{cccc}
\hline & $\mathrm{X}$ & $\mathrm{Y}$ & $\mathrm{Z}$ \\
\hline $\begin{array}{c}\text { Motivasi Berprestasi }(\mathrm{X}) \\
\text { Prestasi Belajar }(\mathrm{Y})\end{array}$ & 0,006 & &
\end{tabular}

Kemandirian Belajar (Z)

Berdasarkan hasil estimasi Path hubungan antara motivasi berprestasi analysis (analisis jalur) pada gambar 2 di atas dapat diketahui bahwa ukuran pengaruh motivasi berprestasi $(\mathrm{X})$ terhadap prestasi belajar $(\mathrm{Y})$ sebesar 0,006 , nilai ini lebih rendah dari ukuran pengaruh sebelum variabel kemandirian belajar dimasukkan sebagai variabel mediasi. Penurunan nilai tersebut menunjukkan bahwa variabel kemandirian belajar memiliki pengaruh pada terhadap prestasi akademik.

Menurut Ghozali (2011) untuk melihat pengaruh variabel mediasi pada suatu model penelitian dapat dilihat dengan membandingkan nilai beta pengaruh total dan nilai beta pengaruh langsung. Berikut nilai total setelah variabel kemandirian belajar dimasukkan sebagai variabel mediasi :

Tabel 3. Pengaruh Total dari Pengaruh Tidak Langsung

\begin{tabular}{cccc}
\hline & $\mathrm{X}$ & $\mathrm{Y}$ & $\mathrm{Z}$ \\
\hline Motivasi Berprestasi (X) & & & \\
Prestasi Belajar (Y) & 0,206 & 0,047 \\
Kemandirian Belajar (Z) & 0,737 & & \\
\hline
\end{tabular}


Ghozali (2011) mengindikasikan bahwa apabila total pengaruh setelah variabel mediasi digunakan dalam estimasi lebih besar dari total pengaruh langsung variabel independen pada variabel dependen maka dapat dinyatakan bahwa variabel tersebut memiliki pengaruh mediasi.

Bedasar pada tabel 3 di atas diketahui bahwa total pengaruh (Total Effect) adalah sebesar 0,206 > 0,181 (nilai koefisien jalur pengaruh langsung pada tabel 1). Dengan demikian dapat dikatakan bahwa besarnya kontribusi dari hubungan antar variabel ini secara tidak langsung adalah sebesar $20 \%$ sedangkan sisanya dipengaruhi oleh variabel lain diluar penelitian ini. Maka jika dilihat dari Nilai total diatas dapat dinyatakan bahwa variabel kemandirian belajar memediasi pengaruh variabel motivasi berprestasi pada variabel prestasi belajar. dengan demikian maka Hipotesis $4(\mathrm{H} 4)$ Diterima.

\section{PEMBAHASAN}

Pengaruh Motivasi Berprestasi (X) terhadap Prestasi Belajar (Y)

Berdasar pada penjabaran hasil penelitian di atas diketahui beta pengaruh motivasi berprestasi $(X)$ terhadap prestasi belajar $(Y)$ adalah sebesar 0,181 dengan nilai $p$ values $0,01<0,05$ (tingkat kepercayaan 95\%). Hal tersebut menunjukkan bahwa secara statistik motivasi berprestasi mempunyai pengaruh positif dan signifikan terhadap prestasi belajar $(\mathrm{Y})$. Dengan demikian maka dapat dikatakan bahwa mahasiswa memiliki motivasi berprestasi yang tinggi selama pembelajaran daring.

Dilihat dari hasil perolehan skor kuesioner, nilai tertinggi dari variabel motivasi berprestasi mahasiswa adalah pada indikator motivasi intrinsik serta relevansi personal dengan item penyataan "saya berpikir bahwa ilmu ekonomi yang saya pelajari akan bermanfaat bagi saya". Hal ini menunjukkan bahwa motivasi berprestasi mahasiswa selama pembalajaran daring lebih banyak di dominasi oleh faktor motivasi intrinsik atau motivasi dari dalam dirinya sendiri.
Motivasi berprestasi merupakan bagian dari motivasi instrinsik yang dapat memberikan pengaruh kuat terhadap pencapaian prestasi belajar mahasiswa. Mahasiswa yang termotivasi secara instrinsik akan merasa senang ketika berhadapan dengan tugas yang harus ia hadapai, mereka juga akan mengusahakan dengan maksimal dalam mengerjakan tugas tersebut. Selain itu motivasi dari dalam diri mahasiswa selama pembelajaran daring ini juga didukung oleh adanya relevansi pribadi yang kuat mengenai persepsi kebermanfaatan pembelajaran yang sedang dijalani, sehingga dengan adanya perasaan kebermanfaatan terhadap apa yang sedang dipelajari tersebut setiap mahasiswa akan lebih mudah untuk memotivasi dirinya.

Penelitian ini diperkuat dengan teori McClelland (1987) yang menyatakan bahwa terdapat beberapa faktor yang mendorong munculnya motivasi pada diri setiap individu, salah satunya adanya faktor akan kebutuhan untuk berprestasi. Mahasiswa yang memiliki kebutuhan motivasi berprestasi tinggi mampu berada pada kondisi dimana mereka dapat menggapai tanggung jawab pribadi untuk dapat memecahkan suatu permasalahan yang dihadapinya serta menentukan langkah acuannya sendiri terhadap umpan balik dari tanggung jawabnya apakah akan gagal atau sukses.

Hasil penelitian ini sependapat dengan penelitian sebelum-sebelumnya. Misalnya saja dengan penelitian Anita \& Wahyudin (2018) yang mengungkapkan bahwa antara motivasi berprestasi pada prestasi belajar terdapat pengaruh positif dan signifikan. Penelitian oleh Kusumadewi (2014) yang menunjukkan bahwa motivasi berprestasi berpengaruh signifikan terhadap prestasi belajar serta mampu meningkatkan prestasi belajar dengan nilai signifikansi sebesar 0,015 . Kemudian penelitian yang dilakukan oleh Marvianto et al. (2020) yang menyatakan bahwa terdapat nilai signifikan yang tinggi pada individu yang memiliki motivasi berprestasi tinggi.

Motivasi berprestasi sangat berperan penting pada pembelajaran daring seperti saat ini, dimana pada pembelajaran daring 
mahasiswa dituntut untuk menjadi pembelajar yang mandiri sehingga mahasiswa diharapkan untuk memiliki motivasi berprestasi yang tinggi dari dalam dirinya. Melalui motivasi berprestasi mahasiswa akan lebih memiliki inisiatif sendiri untuk belajar serta memanage kemampuannya, dengan demikian maka mahasiswa akan lebih mudah dalam mencapai target prestasi belajarnya.

\section{Pengaruh Motivasi Berprestasi $(X)$ terhadap Kemandirian Belajar (Z)}

Berdasar pada hasil penelitian di atas dapat diketahui bahwa beta pengaruh motivasi berprestasi (X) terhadap kemandirian belajar (Z) adalah sebesar 0,737 dengan nilai $p$ values $0,001<0,05$ (tingkat kepercayaan 95\%). Hal tersebut menunjukkan bahwa secara statistik motivasi berprestasi (X) mempunyai pengaruh positif dan signifikan terhadap kemandirian belajar ( $Z$ ). Artinya, semakin tinggi motivasi berprestasi mahasiswa (X) maka akan diikuti pula dengan semakin tinggi kemandirian dalam belajarnya ( $Z$ ) begitupun sebaliknya.

Dilihat dari data kuesioner yang telah diperoleh di lapangan diketahui bahwa mahasiswa dengan nilai perolehan motivasi berprestasinya tinggi cenderung memiliki nilai kemandirian belajar yang tinggi pula sedangkan beberapa mahasiswa yang nilai motivasi berprestasinya rendah maka nilai kemandirian belajarnya juga rendah. Hal ini mengindikasi bahwa terdapat hubungan searah antara motivasi berprestasi mahasiswa dengan kemandirian belajarnya. Menurut Fitriani et al., (2020) dengan motivasi berprestasi yang tinggi, mahasiswa akan lebih mudah untuk terdorong belajar atas inisiatifnya sendiri tanpa bantuan orang lain. Dorongan untuk belajar secara mandiri ini muncul dari adanya inisiatif untuk belajar melalui strategi yang ia terapkan.

Penelitian ini diperkuat dengan teori kontruktivisme Piaget (2002) yang menyatakan bahwa manusia memiliki kebebasan dalam belajar serta memenuhi kebutuhan belajarnya sendiri, hal ini ia lakukan guna mengembangkan kemampuan pada dirinya. Pada teori kontruktivisme ini keterlibatan peserta didik dalam belajar secara mandiri sangat diperlukan guna mencapai keberhasilan belajar melalui motivasi yang diperoleh dari pengalaman belajarnya sendiri. Dapat dikatakan bahwa dengan melalui motivasi yang kuat dari dalam dirinya siswa akan dapat mengembangkan kemampuannya untuk menjadi pembelajar yang mandiri.

Selain itu hasil penelitian ini juga relevan dengan penelitian terdahulu. Pada penelitian terdahulu yang dilakukan oleh Sutama et al. (2018) motivasi berprestasi memiliki pengaruh positif dan signifikan terhadap kemandirian belajar. Hal ini juga sebanding dengan penelitian yang dilakukan oleh Rochimah \& Suryadi (2018) yang juga menunjukkan bahwa terdapat hubungan positif antara motivasi berprestasi dengan belajar mandiri mahasiswa. Kemudian didukung pula oleh penelitian yang dilakukan oleh Fitriani, Haryanto, \& Atmojo (2020) menyatakan bahwa terdapat hubungan positif dan signifikan antara motivasi berprestasi terhadap kemandirian belajar. Hal ini dibuktikan melalui hasil uji koefisiensi determinasi sebesar $49 \%$ motivasi berprestasi berperan menjadi predikator kemandirian belajar. Tingginya motivasi berprestasi seseorang akan mempengaruhi kemandirian belajarnya yang semakin tinggi pula.

Motivasi berprestasi secara langsung juga akan berdampak pada kemandirian belajar mahasiswa, dengan adanya dorongan atau motivasi yang kuat untuk belajar maka makasiswa akan menjadi pembelajar yang mandiri tanpa bergantung dengan pihak lain, motivasi juga akan mendorong individu untuk memaksimalkan waktu dalam belajar, meningkatkan kemampuan personalnya serta bertanggung jawab terhadap tugas dan kewajibannya. Dengan demikian penting bagi mahasiswa untuk dapat meningkatkan motivasi berprestasinya. Dapat disimpulkan bahwa mahasiswa yang memiliki motivasi tinggi cenderung dapat mengontrol kemampuannya sendiri dan pada akhirnya hal tersebut akan menjadi kebiasaan mahasiswa untuk belajar secara mandiri.

\section{Pengaruh Kemandirian Belajar (Z) terhadap Prestasi Belajar (Y) \\ Berdasar pada hasil penelitian di atas dapat diketahui bahwa beta pengaruh}


kemandirian belajar $(Z)$ terhadap prestasi belajar $(Y)$ adalah sebesar 0,047 dengan nilai $p$ values $0,274>0,05$ (tingkat kepercayaan 95\%). Pada hubungan antara kemandirian belajar dan prestasi belajar ini menunjukkan nilai beta positif namun nilai $p$ values ternyata lebih besar dari 0,05, sehingga dapat diartikan bahwa tidak terdapat pengaruh yang signifikan antara kemandirian belajar terhadap prestasi belajar. Kesimpulannya adalah kemandirian belajar bukan merupakan faktor penentu yang dapat mempengaruhi pencapaian prestasi belajar mahasiswa dengan maksimal.

Ketidaksignifikan kemandirian belajar terhadap prestasi belajar ini dapat dilihat melalui hasil kuesioner yang telah dianalisis deskriptif bahwa pada indikator inisiatif dan kemandirian belajar dengan penyataan negatif "saya tidak dapat mengerjakan tugas dengan baik tanpa bantuan orang lain" terdapat 5 mahasiswa yang menjawab sangat setuju dan 16 mahasiswa yang menjawab setuju. Hal ini mengindikasikan bahwa dalam mengerjakan tugas yang diberikan selama pembelajaran daring mahasiswa masih bergantung dengan orang lain. Kondisi empiris yang terjadi dilapangan menunjukkan bahwa mahasiswa lebih sering bekerja sama dengan teman sebayanya dalam menyelesaikan tugas, selain itu pada pembelajaran di perguruan tinggi tugas mahasiswa di dominasi oleh tugas kelompok sehingga untuk memunculkan kemandirian belajar dari setiap mahasiswa dirasa cukup sulit mengingat karakteristik dalam tugas berkelompok dapat diketahui bahwa tidak semua mahasiswa bisa menguasai materi namun saling membagi materi dan kemudian saling melengkapi.

Selain itu indikasi lain yang mendukung bahwa kemandirian belajar tidak berpengaruh secara signifikan terhadap prestasi belajar ditunjukkan pula oleh indikator menerima tanggung jawab terhadap kegiatan belajarnya sendiri dengan item pernyataan positif "saya beranggapan bahwa mempelajari sesuatu secara mandiri adalah lebih baik" pada pernyataan ini terdapat 2 mahaiswa yang menjawab sangat tidak setuju dan 22 mahasiswa yang menjawab tidak setuju. Hal ini menunjukkan bahwa sebagian dari mahasiswa masih belum dapat mengoptimalkan pembelajarannya sendiri, belum adanya inisiatif juga dari sebagian mahasiswa untuk mempelajari serta memahami materi secara mandiri.

Berdasarkan kajian empiris dilapangan dapat dilihat bahwa dalam pembelajaran daring dosen lebih mengoptimalkan pemahaman mahasiswa melalui tugas yang diberikan, sedangkan pemahaman mahasiswa sangat minim terhadap materi, hal ini juga disebabkan oleh terbatasnya ruang gerak antara dosen dan mahasiswa, terbatasnya komunikasi antar pembelajar dan pengajar dan juga mahasiswa kurang dapat membagi waktunya selama belajar dirumah.

Penelitian ini juga sejalan dan diperkuat dengan penelitian sebelumnya yang dilakukan oleh Fitriana, (2015) membuktikan bahwa antara kemandirian belajar pada prestasi belajar tidak terdapat pengaruh yang signifikan. Hal ini juga sependapat dengan penelitian Chanah (2011) yang juga mengatakan tidak terdapat pengaruh dan hubungan antara kemandirian belajar terhadap prestasi belajar matematika. Ketidaksignifikan hubungan antar variabel ini diduga karena terdapat banyak faktor yang lebih dominan untuk dapat mempengaruhi prestasi belajar mahasiswa selama pembelajaran daring. Menurut Slameto (2013) tidak hanya kemandirian belajar saja yang dapat mempengaruhi prestasi belajar, tetapi juga terdapat faktor lainnya seperti minat, bakat, motivasi dll.

Meskipun demikian, kemandirian belajar sangat penting dan dibutuhkan bagi seorang pembelajar. Karena dengan adanya tingkat kemandirian yang tinggi maka pembelajar akan memiliki kesadaran untuk belajar dari dirinya sendiri tanpa bergantung terlebih dahulu dengan orang lain. Hal ini tentunya akan berdampak positif terhadap hasil maupun prestasi belajarnya. Karena seperti yang kita tahu bahwa definisi dari belajar adalah perubahan secara sadar dan terencana yang dilakukan oleh diri sendiri, sehingga sangat penting adanya kemandirian belajar ini utamanya pada pembelajaran daring pada lingkup pendidikan tinggi. Mahasiswa dituntut untuk 
aktif menjadi pembelajar yang mandiri, artinya mahasiswa harus memiliki inisiatif sendiri dalam belajar. Sehingga dengan adanya inisiatif dari diri sendiri dalam belajar ini mahasiswa akan mampu mencapai prestasi belajarnya secara optimal.

Pengaruh Motivasi Beprestasi $(X)$ terhadap Prestasi Belajar (Y) melalui Kemandirian Belajar (Z)

Dari hasil uji hipotesis pada tabel $3 \mathrm{di}$ atas dapat disimpulkan bahwa kemandirian belajar dapat memediasi pengaruh motivasi berprestasi terhadap prestasi belajar. Dengan demikian maka kemandirian belajar dapat dinyatakan sebagai variabel mediasi yang dapat memperkuat hubungan motivasi berprestasi pada prestasi belajar.

Keterkaitan hubungan tersebut dapat dilihat dari hasil penelitian di atas yakni pada tabel 3 diketahui bahwa total pengaruh (total effect) adalah sebesar 0,206 > 0,181 (nilai koefisien jalur pengaruh langsung pada tabel 1). nilai tersebut menyatakan bahwa variabel kemandirian belajar dapat memediasi pengaruh variabel motivasi berprestasi pada variabel prestasi belajar. Hasil penelitian tersebut sejalan dengan hasil penelitian yang dilakukan Sufatihah (2018) yang menyatakan bahwa terdapat hubungan positif dan signifikan baik secara parsial maupun simultan kemandirian belajar dan motivasi berprestasi terhadap prestasi belajar. serta hasil penelitian yang dilakukan oleh Winasih et al. (2018) yang juga menyatakan bahwa terdapat pengaruh positif dan signifikan antara motivasi pencapaian prestasi terhadap prestasi belajar siswa, terdapat pula pengaruh positif dan signifikan kemandirian belajar dengan prestasi belajar siswa.

Motivasi berprestasi dalam hal ini sangat berpengaruh terhadap pencapaian prestasi belajar mahasiswa, dimana mahasiswa dengan motivasi berprestasi tinggi cenderung akan memaksimalkan kemampuannya untuk memenuhi tanggungjawab pribadinya sebagai pembelajar. Dengan adanya motivasi maka seseorang akan tergerak untuk melakukan suatu perubahan, begitu pula dengan motivasi berprestasi yang sangat berperan penting bagi mahasiswa dimana dengan motivasi berprestasi mahasiswa akan terdorong untuk terus belajar sampai mendapatkan umpan balik dari target prestasinya.

Pentingnya motivasi berprestasi ini juga sangat diperlukan ketika pembelajaran daring seperti saat ini, dimana dalam pembelajaran daring mahasiswa dituntut untuk menjadi pembelajar yang mandiri tanpa harus bergantung dengan pihak lain. Mahasiswa dengan motivasi berprestasi tinggi akan memiliki kemandirian yang tinggi pula. Kemandirian dalam belajar ini dapat dilihat melalui adanya inisiatif dan strategi mahasiswa dalam mengolah pembelajarannya sendiri.

\section{SIMPULAN DAN SARAN}

Berdasarkan hasil penelitian yang telah dilakukan peneliti mengenai peran kemandirian belajar dalam memediasi pengaruh motivasi berprestasi terhadap prestasi belajar mahasiswa Jurusan Pendidikan Ekonomi UNESA angkatan 2018 pada pembelajaran daring dapat simpulkan bahwa secara langsung terdapat pengaruh positif dan signifikan antara motivasi berprestasi terhadap prestasi belajar, juga antara motivasi berprestasi terhadap kemandirian belajar. Kemudian secara langsung tidak terdapat hubungan dan pengaruh antara kemandirian belajar terhadap prestasi belajar. Selanjutnya terdapat pengaruh tidak langsung motivasi berprestasi terhadap prestasi belajar melalui kemandirian belajar, sehingga dapat disimpulkan bahwa kemandirian belajar dapat memediasi pengaruh motivasi berprestasi terhadap prestasi belajar.

Berdasarkan hasil dari penelitian ini, penulis memberikan saran bagi mahasiswa agar mampu meningkatkan motivasi instrinsik dari dalam dirinya untuk berprestasi dan juga dibarengi pula dengan meningkatkan kemandirian belajarnya dengan cara menetapkan target dengan berusaha keras dan memiliki inisiatif untuk belajar sendiri. Bagi dosen diharapkan dapat membantu mahasiswanya untuk meningkatkan motivasi serta mandiri dalam belajar melalui optimalisasi pembelajaran kontekstual dengan menekankan pembelajaran pada relevansi dikehidupan nyata. Bagi peneliti selanjutnya disarankan untuk dapat mengembangkan variasi 
variabel lain yang dapat mempengaruhi prestasi pembelajaran selama pembelajaran daring dan juga mengembangkan subjek penelitian agar lebih luas lagi.

\section{DAFTAR PUSTAKA}

Al-Rasyid, H. (1994). Teknik Penarikan Sampel dan Penyusunan Skala. Bandung: Pascasarjana Unpad.

Allen, B. K., Romney, G. W., Dey, P. P., \& Romney, M. D. (2015). Collaborative Academic-Government Agile Development of a Cloud Prototype Fire Retardant Drop Log Application for Wildfire Management Bryan. Journal of Research in Innovative Teaching, 8(1), 99-115.

Baars, M., \& Wijnia, L. (2018). The Relation between Task-Specific Motivational Profiles and Training of Self-Regulated Learning Skills. Learning and Individual Differences,. Learning and Individual Differences, 125-137. Retrieved from https://doi.org/10.1016/j.lindif.2018.05. 007

Balapumi, R., \& Aitken, A. (2012). Concepts and Factors Influencing Independent Learning in IS higher education. ACIS 2012: Proceedings of the 23rd Australasian Conference on Information Systems, 1-10.

Chanah, S. N. (2011). Pengaruh kemandirian belajar dan keaktifan siswa terhadap prestasi belajar matematika. Retrieved from http://digilib.uin-suka.ac.id/5985/

Fitriana, S. (2015). Pengaruh Efikasi Diri, Aktivitas, Kemandirian Belajar Dan Kemampuan Berpikir Logis Terhadap Hasil Belajar Matematika Pada Siswa Kelas Viii Smp Negeri. Journal of Educational Science and Technology (EST), 1(2), 86-101. https://doi.org/10.26858/est.v1i2.1517

Fitriani, W., Haryanto, H., \& Atmojo, S. E. (2020). Motivasi Berprestasi dan Kemandirian Belajar Mahasiswa saat Pembelajaran Daring. Jurnal Pendidikan: Teori, Penelitian, Dan Pengembangan, 5(6), 828-834. Retrieved from http://journal.um.ac.id/index.php/jptpp/ article/view/13639

Ghozali, I. (2011). Aplikasi Analisis
Multivariate dengan program SPSS. Semarang: Badan Penerbit Universitas Diponegoro.

Glynn, S. M., Taasoobshirazi, G., \& Brickman, P. (2009). Science motivation questionnaire: Construct validation with nonscience majors. Journal of Research in Science Teaching, 46(2), 127-146. https://doi.org/10.1002/tea.20267

Guglielmino, P. J., Guglielmino, L. M., \& Long, H. B. (1987). Self-directed learning readiness and performance in the workplace - Implications for business, industry, and higher education. Higher Education, 16(3), 303-317.

https://doi.org/10.1007/BF00148972

Huang, M. B. (2008). Factors Influencing Self-directed Learning Readiness amongst Taiwanese Nursing Students. $1-290$.

Husaini, M. (2014). Pemanfaatan Teknologi Informasi dalam Bidang Pendidikan (EEducation). Jurnall Mikotik, 2(1), 1-5.

Jegede, J. O. ., Jegede, R. T. ., \& Ugodulunwa, C. A. . (1997). Effects of Achievement Motivation and study Habits on Nigerian Secondary School Students' Academic Performance. The Journal of Psychology, 131(5), 523529.

Keirns, J. L. (1999). Designs for Self Instruction: Principle, Process, and Issues in Developing Self-Directed Learning (4th ed.). Massachusetts: Allyn \& Bacon.

Kusumadewi, R. R. (2014). Hubungan Efikasi Diri, Kemandirian Belajar Dan Motivasi Berprestasi Dengan Prestasi Belajar Mahasiswa. Digilib UNS.

Marvianto, R. D., Ratnawati, A., \& Madani, N. (2020). Motivasi Berprestasi sebagai Moderator pada Peranan Kecerdasan Emosi terhadap Prestasi Akademik Mahasiswa. Jurnal Psikologi, 16(1), 74. https://doi.org/10.24014/jp.v16i1.9538

Mc. Clelland, D. C. (1961). The Achieving Society. New York: D. Van Nostrand Company, Inc.

McClelland. (1987). The Achieving Society. Mckendry, S., \& Boyd, V. (2012). Defining the "Independent Learner" in UK Higher Education: Staff and Students' 
Understanding of the Concept. International Journal of Teaching and Learning in Higher EducatioN, 24(2), 209-220.

Piaget, J. (2002). Tingkat Perkembangan Kognitif. Jakarta: Gramedia.

Pilkington, O. A. (2018). Active Learning for an Online Composition Classroom: Blogging as an Enhancement of Online Curriculum. Journal of Educational Technology Systems, 47(2), 1-1. Retrieved from https://doi.org/10.1177/004723951878 8278.

Rochimah, N., \& Suryadi. (2018). Pengaruh Motivasi Berprestasi Dan Kepercayaan Diri Terhadap Belajar Mandiri Mahasiswa. Jurnal Pendidikan Dan Pengajaran, 01(01), 7-13.

Ros, V., Keo, O., \& Sophal, P. (2012). Factors Promoting Independent Learning among Foundation Year Students. The Cambodian Reviews of Language Learning and Teaching, 2, 37-52.

Santrock, J. . (2004). Educational Psychology, 2ndedition (Psikologi Pendidikan, Edisi Kedua). (Terjemahan Tri Wibowo B.S). Jakarta.

Selvi, K. (2010). Motivating Factors in Online Courses. Procedia - Social and Behavioral Sciences, 2(2), 819-824. https://doi.org/https://doi.org/10.1016/j. sbspro.2010.03.110.

Singh, G., 'donoghue, J. O., \& Worton, H. (2005). A Study Into The Effects Of eLearning On Higher Education. Journal of University Teaching \& Learning Practice, 2(1), 13-24.

Slameto. (2013). Belajar dan Faktor-faktor yang Mempengaruhinya. Jakarta: PT. Raja Grafindo Persada.

Sobri, M., \& Moerdiyanto. (2014). Pengaruh Kedisplinan dan Kemandirian Belajar Terhadap Hasil Belajar Ekonomi Madrasah Aliyah di Kecamatan Praya. Harmoni Sosial., 1(1), 43-56.

Sufatihah, I. (2018). Pengaruh Motivasi Berprestasi dan Kemandirian Belajar terhadap Prestasi Belajar Matematika Siswa. JKPM (Jurnal Kajian Pendidikan Matematika), $\quad 3(2), \quad 157$. https://doi.org/10.30998/jkpm.v3i2.277
Sutama, Wahyudiyanto, E., \& Narimo, S. (2018). Lingkungan Teman Sebayamemoderasi Pengaruh Penggunaan Teknologi Informasi, Disiplin Belajar, Dan Motivasi Berprestasi Terhadap Prestasi Akademik. Economic Education Analysis Journal, 7(2), 464-478.

Utami, R. (2019). Analisis Respon Mahasiswa terhadap Penggunaan Google Classroom pada Mata Kuliah Psikologi Pembelajaran Matematika. Prisma, Prosiding Seminar Nasional Matematika, 498-502.

Waskitoningtyas, R. S. (2020). Mahasiswa Pendidikan Matematika Universitas Balikpapan Selama Masa Covid-19. Konferensi Nasional Pendidikan, (12).

Winasih, S. P., Pawenang, S., \& Suhendro. (2018). Dampak Efikasi Diri , Motivasi Pencapaian Prestasi dan Kemandirian Dalam Belajar Terhadap Prestasi Belajar Siswa. Indonesian Economics Business and Management Research, 1(1), 42-46. 